\title{
Penerapan Metode Pembelajaran Learning Together untuk Meningkatkan Hasil Belajar IPA
}

\author{
Warniati \\ Guru Sekolah Dasar Negeri 113 Pekanbaru, Indonesia \\ e-mail:wrniatisdnpku@gmail.com
}

\begin{abstract}
This study is a Classroom Action Research (CAR). This research was carried out in class II-A in SD Negeri 113 Pekanbaru in the even semester of the year 2017/2018. The research began from March 2018 to April 2018. The subject of this class action research was class II-A students at Elementary School 113 of Pekanbaru. The number of students is 32 people, consisting of 15 males and 17 females. The results of this study show the application of learning together methods can improve the learning outcomes of science in class II-A at SD Negeri 113 Pekanbaru academic year 2017/2018. The learning outcomes before CAR were 71.6 with completeness of 20 people and classical completeness of $62.5 \%$. The learning outcomes of the first cycle of meeting 1 were 78.4 with individual completeness of 28 people and classical completeness of $87.5 \%$. The learning outcomes of the first cycle of meeting 2 were 80.0 with completeness of 29 people and classical completeness of $90.6 \%$. The learning outcomes of meeting 3 cycle II were 82.8 with completeness of 30 people and classical completeness of $93.8 \%$. The learning outcomes of meeting 4 second cycle were 84.7 with completeness of 31 people and classical completeness of $96.9 \%$.
\end{abstract}

Keywords: Learning Together, Learning Outcomes

\section{PENDAHULUAN}

Pendidikan di sekolah dasar merupakan dasar keberhasilan pendidikan selanjutnya, anak merupakan tunas bangsa yang masih dalam proses pertumbuhan dan perkembangan baik jasmani maupun rohaninya, sehingga diharapkan di kemudian hari menjadi anak yang tumbuh dewasa dengan keadaan yang sehat serta mempunyai rasa tanggungjawab dan berguna bagi bangsa dan negaranya, untuk itu anak sekolah dasar harus disiapkan sesuai dengan tahap perkembangan dan kematangannya (Desmita, 2009).

Tujuan pendidikan pada dasarnya mengantarkan peserta didik menuju perubahanperubahan tingkah laku baik intelektual, moral maupun sosial agar dapat hidup mandiri sebagai makhluk individu dan makhluk sosial. Berhasil tidaknya pencapaian tujuan pendidikan ini banyak bergantung pada proses belajar. Belajar adalah proses mereaksi terhadap semua situasi yang ada disekitar individu (Sudjana, 2014).

Belajar adalah suatu proses yang kompleks yang terjadi pada setiap diri orang sepanjang hidupnya. Proses belajar itu terjadi karena adanya interaksi antara seseorang dengan lingkungannya. Oleh karena itu, belajar dapat terjadi kapan saja dan dimana saja. Salah satu pertanda bahwa seseorang telah belajar adalah adanya perubahan tingkah laku pada diri orang yang mungkin disebabkan oleh terjadinya perubahan pada tinngkat pengetahuan, keterampilan atau sikapnya (Arsyad, 2009).

Proses belajar mengajar merupakan suatu rentetan kegiatan guru menumbuhkan organisasi proses belajar mengajar yang efektif, yang meliputi: tujuan pengajaran, pengaturan penggunaan waktu luang, pengaturan ruang dan alat perlengkapan pelajaran di kelas, serta pengelompokan siswa dalam belajar (Djamarah dan Zain, 2012). 
Proses belajar mengajar IPA di kelas II-A SD Negeri 113 Pekanbaru belum berlangsung optimal. Hal ini dapat terlihat dari hasil belajar siswa yang diperoleh pada saat dilaksanakan ulangan harian. Hanya 62.5\% siswa mencapai KKM. Rendahnya hasil belajar siswa ini disebabkan karena kurang bervariasinya metode pembelajaran yang diterapkan oleh guru. Hal ini menimbulkan kejenuhan bagi siswa di dalam mengikuti proses pembelajaran dan berdampak pada penurunan hasil belajar siswa. Untuk meningkatkan hasil belajar siswa diperlukan suatu perubahan di dalam proses pembelajaran. Penerapan metode pembelajaran yang tepat dapat menunjang proses pembelajaran berjalan maksimal. Salah satu metode pembelajaran yang dapat diterapkan adalah metode learning together.

Metode learning together merupakan pembelajaran cooperative yang dilakukan dengan cara mengelompokkan peserta didik yang berbeda tingkat kemampuannya dalam suatu organisasi. Guru bertugas mengawasi kelompok-kelompok ini berdasarkan pada lima elemen cooperative yaitu interdependensi positif, akuntabilitas individu, interaksi lngsung, keterampilam-keterampilan sosial, dan pemrosesan kelompok (Ibrahim, 2010). Melalui penerapan metode learning together ini diharapkan dapat meningkatkan hasil belajar siswa.

\section{METODOLOGI}

Penelitian ini dilaksanakan di kelas II-A SD Negeri 113 Pekanbaru pada semester genap tahun pembelajaran 2017/2018. Penelitian ini dimulai dari bulan Maret 2018 sampai dengan bulan April 2018.

Subjek penelitian tindakan kelas ini dilakukan pada siswa kelas II-A SD Negeri 113 Pekanbaru. Jumlah siswa 32 orang, terdiri dari 15 orang putra dan 17 orang putri. Penelitian ini merupakan Penelitian Tindakan Kelas (PTK). Berikut diuraikan prosedur penelitian yang telah dilaksanakan dalam dua siklus yaitu: (a) perencanaan, (b) tahap pelaksanaan, (c) tahap observasi, dan (d) Refleksi.

\section{HASIL PENELITIAN DAN PEMBAHASAN}

Penelitian ini dilaksanakan pada bulan Maret sampai dengan bulan Maret 2018 di Kelas II-A SD Negeri 113 Pekanbaru yang terdiri dari dua siklus. Tiap siklus terdiri dari dua pertemuan. Penelitian tindakan kelas ini menerapkan metode pembelajaran learning together di dalam proses pembelajaran IPA.

Metode learning together adalah pembentukan kelompok-kelompok yang beranggotakan berangotakan 4 siswa yang memiliki kemampauan akdemik yang berbedabeda. Tiap kelompok bekerjasama untuk menyelesaikan tugas yang diberikan oleh guru dan guru bertugas mengawasi kerja kelompok.

Tabel 1. Hasil Belajar Siswa Sebelum PTK

\begin{tabular}{cllc}
\hline No & \multicolumn{1}{c}{ Interval nilai } & \multicolumn{1}{c}{ Kategori } & Jumlah \\
\hline 1 & $92-100$ & Sangat Baik & - \\
2 & $82-91$ & Baik & - \\
3 & $72-81$ & Cukup & 20 \\
4 & $62-71$ & Kurang & 2 \\
5 & $\leq 61$ & Sangat Kurang & 10 \\
\hline Jumlah & & 32 \\
\hline
\end{tabular}

Berdasarkan tabel 1. di atas, dapat dijelaskan bahwa sebelum PTK tidak ada siswa yang memperoleh nilai dengan interval 92-100. Tidak ada siswa yang memperoleh interval 
nilai 82-91. Interval nilai $72-81$ sebanyak 20 orang siswa. Interval nilai 62-71 sebanyak 2 orang dan $\leq 61$ sebanyak 10 orang. Rata-rata kelas yang diperoleh adalah 71.6 dengan kategori kurang. Ketuntasan individu sebanyak 20 orang siswa dari 32 siswa. Ketuntasan klasikal sebesar $62.5 \%$ dengan kategori tidak tuntas. Secara klasikal dinyatakan tidak tuntas karena kriteria ketuntasan klasikal minimal 85\% dari siswa yang ada di dalam kelas.

Tabel 2. Hasil Belajar Siklus I

\begin{tabular}{crlccc}
\hline \multirow{2}{*}{ No } & \multirow{2}{*}{ Interval nilai } & & \multirow{2}{*}{ Kategori } & Pertemuan 1 & Pertemuan 2 \\
\cline { 4 - 5 } & & & Jumlah & Jumlah \\
\hline 1 & $92-100$ & Sangat Baik & - & 1 \\
2 & $82-91$ & Baik & 2 & 2 \\
3 & $72-81$ & Cukup & 26 & 26 \\
4 & $62-71$ & Kurang & 1 & 2 \\
5 & $\leq 61$ & Sangat Kurang & 3 & 1 \\
\hline \multicolumn{2}{l}{ Jumlah } & & 32 & 32 \\
\hline
\end{tabular}

Berdasarkan tabel 2. di atas, dapat diketahui bahwa pada siklus I pertemuan 1 tidak ada siswa yang memperoleh nilai dengan interval nilai 92-100. Interval nilai 82-91 sebanyak 2 orang siswa. Interval nilai $72-81$ sebanyak 26 orang siswa. Interval nilai $62-71$ sebanyak 1 orang dan $\leq 61$ sebanyak 3 orang. Pada siklus I pertemuan 1 rata-rata kelas yang diperoleh adalah 78.4 dengan kategori cukup. Ketuntasan individu sebanyak 28 orang siswa dari 32 siswa. Ketuntasan klasikal sebesar $87.5 \%$ dengan kategori tuntas.

Pada pertemuan 2 siswa yang memperoleh nilai dengan interval nilai 92-100 sebanyak 1 orang siswa. Interval nilai 82-91 sebanyak 2 orang siswa. Interval nilai 72-81 sebanyak 26 orang siswa. Interval nilai 62-71 sebanyak 2 orang dan $\leq 61$ sebanyak 1 orang. Pada siklus I pertemuan 2 rata-rata kelas yang diperoleh adalah 80.0 dengan kategori cukup. Ketuntasan individu sebanyak 29 orang siswa dari 32 siswa. Ketuntasan klasikal sebesar $90.6 \%$ dengan kategori tuntas.

Untuk refleksi siklus I ini ditemukan beberapa permasalahan atau kendala yang antara lain adalah interaksi tatap muka para siswa pada saat bekerja dalam kelompok-kelompok masih belum optimal. Kemudian masih minimnya tanggung jawab individual para siswa di dalam menguasai materi pelajaran tersebut. Rencana yang dilakukan peneliti untuk memperbaiki peermasalahan tersebut pada siklus selanjutnya adalah peneliti akan lebih maksimal di dalam melakukan bimbingan kelompok siswa sehingga dapat tercipta interaksi tatap muka antar siswa dengan maksimal dan dapat meningkatkan tanggung jawab individual para siswa di dalam menguasai materi pelajaran.

Tabel 3. Hasil Belajar Siswa Siklus II

\begin{tabular}{cllcc}
\hline \multirow{2}{*}{ No } & \multirow{2}{*}{ Interval nilai } & \multirow{2}{*}{ Kategori } & Pertemuan 3 & Pertemuan 4 \\
\cline { 4 - 5 } & & & Jumlah & Jumlah \\
\hline 1 & $92-100$ & Sangat Baik & 3 & 4 \\
2 & $82-91$ & Baik & 5 & 8 \\
3 & $72-81$ & Cukup & 22 & 19 \\
4 & $62-71$ & Kurang & 2 & 1 \\
5 & $\leq 61$ & Sangat Kurang & - & - \\
\hline \multicolumn{2}{l}{ Jumlah } & & 32 & 32 \\
\hline
\end{tabular}

Berdasarkan tabel 3. di atas, dapat diketahui bahwa pada siklus II pertemuan 3 siswa yang memperoleh nilai dengan interval nilai 92-100 sebanyak 3 orang siswa. Interval nilai 
82-91 sebanyak 5 orang siswa. Interval nilai 72-81 sebanyak 22 orang siswa. Interval nilai 62-71 sebanyak 2 orang. Pada siklus II pertemuan 3 rata-rata kelas yang diperoleh adalah 82.8 dengan kategori baik. Ketuntasan individu sebanyak 30 orang siswa dari 32 siswa. Ketuntasan klasikal sebesar $93.8 \%$ dengan kategori tuntas.

Pada pertemuan 4 siswa yang memperoleh nilai dengan interval nilai 92-100 sebanyak 4 orang siswa. Interval nilai 82-91 sebanyak 8 orang siswa. Interval nilai 72-81 sebanyak 19 orang siswa. Interval nilai 62-71 sebanyak 1 orang. Pada siklus II pertemuan 4 rata-rata kelas yang diperoleh adalah 84.7 dengan kategori baik. Ketuntasan individu sebanyak 31 orang siswa dari 32 siswa. Ketuntasan klasikal sebesar 96.2\% dengan kategori tuntas.

Refleksi yang dilakukan pada siklus II ini adalah permasalahan atau kendala pada siklus I tidak ditemukan lagi pada siklus II ini. Interaksi tatap muka siswa di dalam mengerjakan tugas kelompok telah terbentuk dengan baik. Tanggung jawab individu juga telah dapat tumbuh dengan baik. Hasil belajar siswa mengalami peningkatan dari siklus I yaitu 79.2 dengan kategori cukup dan meningkat menjadi 83.8 dengan kategori baik pada siklus II.

Metode learning together merupakan pembelajaran cooperative yang dilakukan dengan cara mengelompokkan peserta didik yang berbeda tingkat kemampuannya dalam suatu organisasi. Guru bertugas mengawasi kelompok-kelompok ini berdasarkan pada lima elemen cooperative yaitu interdependensi positif, akuntabilitas individu, interaksi lngsung, keterampilam-keterampilan sosial, dan pemrosesan kelompok (Ibrahim, 2010).

Melalui penerapan metode learning together ini dapat menciprakan interaksi langsung di dalam kelompok. Setiap anggota kelompok saling membantu anggota lainnya di dalam menyelesaikan tugas yang diberikan oleh guru. Hal ini dapat membantu siswa di dalam memahami materi pelajaran sehingga berdampak langsung pada peningkatan hasil belajar siswa.

Hasil belajar siswa pada siklus I pertemuan 1 adalah 78.4 dengan kategori cukup dan pada pertemuan 2 adalah 80.0 dengan kategori cukup. Pada siklus II pertemuan 3 hasil belajar siswa adalah 82.8 dengan kategori baik dan pada pertemuan 4 adalah 84.7 dengan kategori baik. Peningkatan hasil belajar siswa ini menunjukkan bahwa penerapan metode pembelajaran learning together dapat meningkatkan hasil belajar IPA pada siswa kelas II-A SD Negeri 113 Pekanbaru tahun pelajaran 2017/2018.

\section{KESIMPULAN DAN SARAN}

\section{Kesimpulan}

Berdasarkan penelitian yang telah dilaksanakan pada siklus I dan II, maka dapat disimpulkan bahwa:

- Penerapan metode pembelajaran learning together dapat meningkatkan hasil belajar IPA pada siswa kelas II-A SD Negeri 113 Pekanbaru tahun pelajaran 2017/2018.

- Hasil belajar sebelum PTK adalah 71.6 dengan ketuntasan individu 20 orang dan ketuntasan klasikal adalah 62.5\%. Hasil belajar siklus I pertemuan 1 adalah 78.4 dengan ketuntasan individu 28 orang dan ketuntasan klasikal adalah 87.5\%. Hasil belajar siklus I pertemuan 2 adalah 80.0 dengan ketuntasan individu 29 orang dan ketuntasan klasikal adalah 90.6\%. Hasil belajar siklus II pertemuan 3 adalah 82.8 dengan ketuntasan individu 30 orang dan ketuntasan klasikal adalah 93.8\%. Hasil 
belajar siklus II pertemuan 4 adalah 84.7 dengan ketuntasan individu 31 orang dan ketuntasan klasikal adalah 96.9\%.

\section{Saran}

Berdasarkan hasil penelitian maka peneliti menyampaikan saran-saran sebagai berikut :

- Kepada guru agar dapat menerapkan metode pembelajaran learning together ini dengan memaksimalkan tanggung jawab individu siswa di dalam memahami materipelajaran dan menyelasaikan tugas kelompok.

- Bagi peneliti selanjutnya dapat mengkombinasikan metode pembelajaran learning together dengan metode pembelajaran lainnya yang sesuai.

\section{REFERENSI}

Arsyad, A. 2009. Media Pembelajaran. Jakarta: Raja Grafindo Persada.

Desmita. 2009. Psikologi Perkembangan Peserta Didik. Bandung: PT Remaja Rosdakarya.

Djamarah, Syaiful B. dan Azwan Zain. 2012. Strategi Belajar Mengajar. Jakarta: Rineka Cipta.

Hamalik, Oemar. 2011. Proses Belajar Mengajar. Jakarta: Bumi Aksara.

Ibrahim. 2010. Pembelajaran Cooperative. Surabaya: Unesa.

Jihad, Asep dan Abdul Aziz. 2009. Persuasi Pembelajaran. Yogyakarta: Mahl Persindo.

Rusman. 2012. Model Pembelajaran. Jakarta. PT Raja Grafindo Persada.

Sanjaya, W. 2011. Strategi Pembelajaran Berorientasi Standar Proses Pendidikan. Jakarta: Prenada Media Group.

Slavin, R.E. 2010. Cooperative Learning. Jakarta: Kencana Prenada Media Group.

Sudjana, Nana. 2014. Penilaian Hasil Proses Belajar Mengajar. Jakarta: Remaja Rosdakarya. 